\title{
Effects of bone morphogenic protein 4 (BMP4) and its inhibitor, Noggin, on in vitro maturation and culture of bovine preimplantation embryos
}

\author{
Isabel La Rosa', Luiz SA Camargo ${ }^{2}$, Michele M Pereira², Rafael Fernandez-Martin ${ }^{1,4}$, Dante A Paz ${ }^{3,4}$, \\ Daniel F Salamone $e^{1,4^{*}}$
}

\begin{abstract}
Background: BMP4 is a member of the transforming growth factor beta (TGFbeta) superfamily and Noggin is a potent BMP inhibitor that exerts its function by binding to BMPs preventing interactions with its receptors. The aim of this work was to investigate the role of BMP4 and Noggin, on oocytes in vitro maturation (m experiments) and embryos in vitro development (c experiments) of bovine.
\end{abstract}

Methods: For m experiments, COCs were collected from slaughterhouse ovaries and in vitro matured in TCM with $100 \mathrm{ng} / \mathrm{ml}$ of either BMP4 or Noggin. After $24 \mathrm{~h}$, the nuclear stage of the oocytes was determined by staining with Hoechst 33342. In addition, RT-qPCR was performed on MII oocytes to study the relative concentration of ZAR1, GDF9, BAX, MATER and HSP70 transcripts. Treated oocytes were submitted to parthenogenic activation (PA) or in vitro fertilization (IVF) and cultured in CR2. For c experiments, non-treated matured oocytes were submitted to PA or IVF to generate embryos that were exposed to $100 \mathrm{ng} / \mathrm{ml}$ of BMP4 or Noggin in CR2 until day nine of culture. Cleavage, blastocyst and hatching rates, expression pattern of the transcription factor Oct-4 in blastocysts and embryo cell number at day two and nine post-activation or fertilization were evaluated.

Results: We found that Noggin, as BMP4, did not affect oocyte nuclear maturation. Noggin supplementation up-regulated the expression of HSP70 and MATER genes in matured oocytes. Moreover, BMP4 during maturation increased the proportion of Oct-4 positive cells in parthenogenic embryos. On the other hand, when Noggin was added to embryo culture medium, developmental rates of parthenogenic and in vitro fertilized embryos were reduced. However, BMP4 addition decreases the development only for in vitro fertilized embryos. BMP4 and Noggin during culture reduced the proportion of Oct-4-expressing cells.

Conclusions: Our results show that BMP4 is implicated in bovine oocytes maturation and embryo development. Moreover, our findings demonstrate, for the first time, that a correct balance of BMP signaling is needed for proper pre-implantation development of bovine embryos.

\section{Background}

Bone Morphogenetic Protein 4 is a member of the transforming growth factor beta (TGF $\beta$ ) superfamily which controls numerous events of embryonic, fetal and even adult development in all vertebrates [1]. Intracellular mediators of BMPs are Smad proteins which form a complex that is then translocated to the nucleus and

\footnotetext{
* Correspondence: salamone@agro.uba.ar

'Laboratory of Animal Biotechnology, Agriculture Faculty, University of Buenos Aires (UBA), Argentina

Full list of author information is available at the end of the article
}

regulates gene expression [2]. Noggin is a potent inhibitor of BMPs that directly binds to BMP members, specifically 2, 4 and 7, and blocks the sites required for interaction with BMP receptors. It belongs to the so called "ligand traps" group [3] and is a critical regulator of BMP signaling.

BMP4 is expressed first in stromal cells and later in follicular development, in theca cells. Its receptors are found in granulosa cells as well as in the oocyte itself $[4,5]$ and it is in charge of primordial to primary follicular transition, stimulates granulose cells proliferation,

\section{Biomed Central}


pre-antral follicular growth and follicular survival and regulates steroideogenesis in granulosa cells [6]. Other TGF $\beta$ members, such as BMP15 and GDF9, are expressed by the oocyte also in many species as cats [7], mice [8], rats [9], hens [10], goats [11], and cattle [12]. The importance of BMPs for the female reproductive system has been evidenced by spontaneous mutations of these genes in sheep $[13,14]$ influencing ovulation rates. Of all the ovarian BMPs the most associated with the stem cells properties is in fact BMP4. Therefore, it could be a potencial regulator of this cell capacity in bovine embryos. BMP4 maintains the pluripotency of primordial germ cells [15] and embryonic stem cells (ESC) in mice [16]. In contrast, BMP4 inhibition with Noggin is required to maintain pluripotency of embryonic stem cells in the human [17]. In domestic species, ESCs have not been established yet but a study by Pant and Keefer [18] showed that BMP4 inhibition with Noggin increases the amount of Nanog transcripts (a pluripotent-related factor) in bovine inner cell mass (ICM) explants. To date, the specific role of this factor in bovine pluripotent state has not been elucidated. The POU transcription factor Oct-4, which is also related to pluripotency, is not expressed only in the ICM in bovine but it could be implicated in trophoblastic expansion where intense cellular division precedes differentiation and so it is important for embryo implantation $[19,20]$. Moreover, in later developmental stages, BMP4 induces embryonic and extraembryonic mesoderm formation $[21,22]$ and is also related to vasculogenesis [23] in the embryo as well as in the developing placenta. As a result it is of major importance in the success of pregnancy.

The aim of this work was to investigate the role of BMP4 and its inhibitor, Noggin, in oocyte maturation and development of bovine embryos produced by parthenogenesis and in vitro fertilization. Several developmental and molecular aspects were evaluated. These included meiotic stage and the amount of several transcripts in oocytes, cleavage and blastocyst rates, embryo cell number and Oct-4 protein expression.

\section{Methods}

\section{Reagents}

Except where otherwise indicated, all chemicals were obtained from Sigma Chemical Company (St. Louis, MO, USA).

\section{Experimental design}

\section{Maturation $(m)$ experiments}

Oocytes were in vitro matured under three different conditions [BMP4 (mBMP4), Noggin (mNoggin) and Control (mControl)] and then submitted to parthenogenic activation (PA) or in vitro fertilization (IVF). Nuclear stage was analyzed and transcripts of different genes were quantified by RT-qPCR on oocytes matured under the three treatments.

\section{Culture (c) experiments}

Embryos were produced by PA or IVF and then cultured in CR2 medium (cControl) or with the addition of BMP4 (cBMP4) or Noggin (cNoggin).

For both $\mathrm{m}$ and $\mathrm{c}$ experiments, numbers of cleaved embryos and their cell numbers were recorded on day two and numbers of blastocysts and their cell numbers were recorded on day nine post fertilization/activation. Oct-4 immunostaining was performed on blastocysts from the three treatments.

\section{Oocyte collection and maturation}

Bovine ovaries were obtained from a slaughter house and maintained at $25^{\circ} \mathrm{C}$ until processed. Cumulus-oocyte complexes (COCs) were aspirated using an 18-G needle and a $10 \mathrm{ml}$ syringe and rinsed in phosphate buffered solution (PBS, Gibco 14190, Grand Island, NY, USA) supplemented with $1 \%$ antibiotic-antimycotic (Gibco 15240), and 10\% Adult Bovine Serum (Internegocios, Mercedes, Buenos Aires, Argentine). Maturation was performed in $100 \mu \mathrm{l}$ microdroplets of medium 199 (TCM, Gibco 11150) supplemented with $10 \%$ Fetal Bovine Serum (FBS, Internegocios), $1 \%$ antibiotic-antimycotic, $20 \mu \mathrm{M}$ cysteamine (M-9768), $0.1 \mathrm{mM}$ sodium pyruvate (S-8636), and $2 \mathrm{mM} \mathrm{FSH}$ (Folltropin-V, Bioniche, Belleville, ON, Canada), under mineral oil (M-8410). Maturation conditions were $6.5 \% \mathrm{CO}_{2}$ in humidified atmosphere at $39^{\circ} \mathrm{C}$.

For $\mathrm{m}$ experiments, COCs were matured as described above but FBS was replaced by $0.6 \% \mathrm{w} / \mathrm{v}$ fatty acid-free bovine serum albumin (faf BSA, A-6003). COCs were matured in the presence of $100 \mathrm{ng} / \mathrm{ml}$ of BMP4 (314bp-010, R\&D Systems, Minneapolis, MN, USA) or Noggin (N-6784). A Control group consisted of COCs matured without BMP4 or Noggin.

\section{Nuclear maturation}

Cumulus cells were removed from COCs by vortexing for $3 \mathrm{~min}$ in $1 \mathrm{mg} / \mathrm{ml}$ hyaluronidase $(\mathrm{H}-4272)$ in Hepesbuffered Tyrode's medium containing albumin, lactate and pyruvate (TALP-H). After several rinses in TALP$\mathrm{H}$, DNA was stained with $2 \mu \mathrm{g} / \mathrm{ml}$ of Hoechst 33342 (B-2261) in TCM for 10 min and oocyte nuclear status was determined under UV light on an inverted microscope. A holding pipette was used to rotate the oocytes.

\section{Parthenogenic activation}

Denuded oocytes were chemically activated in TALP-H with $5 \mu \mathrm{M}$ ionomycin (I24222, Invitrogen, Chicago, IL, USA) for $4 \mathrm{~min}$, rinsed several times in TALP-H and immediately incubated in a $100 \mu \mathrm{l}$ microdrop of TCM containing $1.9 \mathrm{mM}$ 6-diaminopuridine (D-2629), for $3 \mathrm{~h}$. 
Afterwards, oocytes were rinsed four times in TALP-H and transferred to culture medium.

\section{In vitro fertilization}

Frozen bovine sperm were thawed at $35^{\circ} \mathrm{C}$ in a waterbath and centrifuged twice at $490 \mathrm{~g}$ in BO solution [24] supplemented with $0.4 \%$ caffeine (C-4144) and $0.02 \%$ heparin (H-3149) (Sperm washing solution, SWS). The pellet was resuspended in 50\% SWS and 50\% BO solution supplemented with $2 \%$ faf BSA. Sperm concentrations were adjusted to $20 \times 10^{6} / \mathrm{ml}$ and $100 \mu \mathrm{l}$-microdrops were placed under mineral oil. Following $22 \mathrm{~h}$ maturation, COCs were rinsed in TALP-H and co-incubated with sperm for $5 \mathrm{~h}$. Presumptive zygotes were vortexed for $30 \mathrm{sec}$ and rinsed three times in TALP-H before being transferred to culture medium.

\section{Embryo culture}

For $\mathrm{m}$ experiments, presumptive zygotes were cultured in $100 \mu \mathrm{l} \mathrm{microdrops} \mathrm{of} \mathrm{serum-free} \mathrm{CR2,} \mathrm{without} \mathrm{co-}$ culture. For c experiments, they were randomly assigned to one of the treatments according to the experimental design (i.e. serum-free CR2 without co-culture (Control) or supplemented with $100 \mathrm{ng} / \mathrm{ml}$ of either BMP4 or Noggin). Culture conditions were $6.5 \% \mathrm{CO}_{2}$ in humidified atmosphere at $39^{\circ} \mathrm{C}$. Fifty percent of the culture medium was renewed on days 2,5 and 7 of culture.

\section{Embryo development}

Cleavage, blastocyst and hatching rates were assessed on day 2 and 9 post fertilization/activation. On day 2, embryonic cell numbers were recorded using an inverted microscope.

Blastocyst total cell numbers were assessed on day 9 of culture, by nuclear staining with $2 \mu \mathrm{g} / \mathrm{ml}$ of Hoechst 33342 in CR2 for $10 \mathrm{~min}$. Then, embryos were placed between a slide and a coverslip and nuclei were counted under UV light using an inverted microscope.

\section{RNA extraction, quantitative Real Time-Polymerase Chain Reaction (RT-qPCR)}

Denuded oocytes were classified by the presence of the first polar body, and kept in RNA later ${ }^{\circledR}$ (AM 7020, Ambion, Foster City, CA, USA) at $-20^{\circ} \mathrm{C}$ until RNA extraction. Total RNA extraction was performed using a Rneasy Micro kit (Qiagen, Valencia, CA, USA) protocol, according to the manufacturer's instructions, and treated with DNAse. Reverse transcriptions were performed with total RNA from 3 pools of 10 oocytes, using a Superscript ${ }^{\mathrm{TM}}$ III first strand synthesis kit (Invitrogen). Relative quantification was performed in triplicate using real time PCR (ABI Prism1 7000, Applied Biosystems, Foster City, CA, USA) and reactions using a mixture of iTaqTM SYBR1Green Supermix with ROX (Bio-Rad,
Waltham, MA, USA) with cDNA equivalent to 1.2 oocytes and gene specific primers. Template cDNA was denatured at $95^{\circ} \mathrm{C}$ for $10 \mathrm{~min}$, followed by 45 cycles of $95^{\circ} \mathrm{C}$ for $15 \mathrm{sec}$; gene-specific primer annealing temperature was applied for $30 \mathrm{sec}$, and elongation was carried out at $72^{\circ} \mathrm{C}$ for $45 \mathrm{sec} / 60^{\circ} \mathrm{C}$ for $30 \mathrm{~min}$ (Table 1). After each PCR run, a melting curve analysis was performed for each sample to confirm that a single specific product was generated. Amplicon size was confirmed by ethidium bromide stained-2\% agarose gel electrophoresis. Negative Controls, comprised of the PCR reaction mix without nucleic acid, were also run with each group of samples.

Expressions of the GAPDH and $\beta$-ACTIN genes were used as endogenous references and oocytes from Controls were used as calibrators. Calculations of relative quantification were performed with the REST 2008 software version 2.0.7. Values are shown as n-fold difference relative to the calibrator. The evaluated transcripts were related with stress $(H S P 70)$, apoptosis $(B A X)$, oocyte quality (GDF9) and oocyte developmental competence (MATER and ZAR1).

\section{Immunocytochemistry}

Zona-intact blastocysts were fixed in $4 \%$ formaldehyde (F-1635) in PBS for 20 min, rinsed in PBS with $0.4 \%$ BSA (A-7906) for $20 \mathrm{~min}$ and permeabilized in $0.1 \%$ Triton-X (T-9284) in PBS for $15 \mathrm{~min}$. Non-specific immunoreactions were blocked by incubation, for 30 min, in blocking solution consisting of 3\% FBS and $0.2 \%$ Tween $^{\circledR} 20$ (H5152, Promega, Madison, WI, USA) in PBS. Incubation with the primary antibody against Oct4(goat polyclonal IgG, SC-8628 Santa Cruz Biotechnology, Santa Cruz, CA, USA) diluted 1:100 in blocking solution, was performed for $1 \mathrm{~h}$. Embryos were then rinsed in blocking solution for $15 \mathrm{~min}$. Incubation with the secondary antibody (Alexa 488-donkey anti-goat IgG, A11055, Molecular Probes Inc. Eugene, OR, USA) diluted 1:1000 in blocking solution, was performed for $45 \mathrm{~min}$ in the dark. Embryos were then rinsed in blocking solution and counterstained with $0.01 \mathrm{mg} / \mathrm{ml}$ propidium iodide (P-4864) in blocking solution for $10 \mathrm{~min}$ in the dark. Blastocysts not exposed to primary antibody were used as negative controls. All the stages were performed at room temperature. Embryos were mounted in a drop of cool 70\% glycerol (G-9012) in PBS on a microscope slide and covered with a coverslip, using small droplets of wax to protect embryos from collapse. Images of serial optical sections were recorded every $5 \mu \mathrm{m}$ with a confocal microscope (Olympus FV300), using software (Olympus Fluoview version 3.3) associated with a fluorescence microscope (Olympus BX 61) and $488 \mathrm{~nm}$ and $543 \mathrm{~nm}$ lasers to visualize Oct-4 positive cells and total nuclei respectively. 
Table 1 Primer sequences and PCR conditions

\begin{tabular}{|c|c|c|c|c|}
\hline Gene & Primer Sequence & $\begin{array}{l}\text { Annealing } \\
\text { Temperature }\end{array}$ & $\begin{array}{l}\text { Product Length } \\
\text { (bp) }\end{array}$ & $\begin{array}{l}\text { GenBank } n^{\circ} \text { of access/ } \\
\text { Reference }\end{array}$ \\
\hline HSP7O & $\begin{array}{l}\text { F 5'AACAAGATCACCATCACCAACG } 3^{\prime} \\
\text { R 5TCCTTCTCCGCCAAGGTGTTG3' }\end{array}$ & $59^{\circ} \mathrm{C}$ & 275 & NM174550 \\
\hline$B A X$ & $\begin{array}{l}\text { F 5'TTTGCTTCAGGGTTCATCCAGGA3' } \\
\text { R 5'CAGCTGCGATCATCCTCTGCAG3' }\end{array}$ & $64^{\circ} \mathrm{C}$ & 174 & NM173894 \\
\hline ZAR1 & $\begin{array}{l}\text { F 5'TGCCGAACATGCCAGAAG3' } \\
\text { R 5'TCACAGGATAGGCGTTTGC3' }\end{array}$ & $53^{\circ} \mathrm{C}$ & 188 & NM_001076203 \\
\hline MATER & $\begin{array}{l}\text { F 5TAATGACGACGCTGTGTTCTG3' } \\
\text { R 5'GCGGTTCTCAGGTTCTTCAG3' }\end{array}$ & $53^{\circ} \mathrm{C}$ & 206 & NM_001007814 \\
\hline GDF9 & $\begin{array}{l}\text { F 5'GACCCCTAAATCCAACAGAA3' } \\
\text { R 5'AGCAGATCCACTGATGGAA3' }\end{array}$ & $53^{\circ} \mathrm{C}$ & 120 & NM_174681 \\
\hline $\begin{array}{l}\beta \text {-ACTIN } \\
\text { (endogenous) }\end{array}$ & $\begin{array}{l}\text { F 5'GACATCCGCAAGGACCTCTA3' } \\
\text { R 5'ACATCTGCTGGAAGGTGGAC3' }\end{array}$ & $53^{\circ} \mathrm{C}$ & 205 & NM_173979 \\
\hline GAPDH (endogenous) & $\begin{array}{l}\text { F 5'CCAACGTGTCTGTTGTGGATCTGA3' } \\
\text { R } \\
\text { 5'GAGCTTGACAAAGTGGTCGTTGAG3' }\end{array}$ & $53^{\circ} \mathrm{C}$ & 237 & MOUROT et al. [33] \\
\hline
\end{tabular}

Primer sequences and PCR conditions used for relative gene expression analysis.

\section{Statistical analysis}

Data relative to nuclear stages were analyzed by the Fisher test. Cleavage, blastocyst and hatching rates were analyzed by Chi-square test. Blastocyst total cell numbers were analyzed by one-way ANOVA, using the Graph Pad Prism 4 software. Embryo cell number on day 2 was analyzed with a three by three table and Chisquare test of independence. The proportion of Oct-4 positive cells over total cell number was analyzed by the 'Difference of proportions test' using statistical INFOSTAT (2007) software. In all cases $\mathrm{p}<0.05$ was considered to be significant.

\section{Results}

\section{BMP4 and Noggin during maturation}

\section{Nuclear maturation and gene expression}

The addition of BMP4 or Noggin to in vitro maturation (IVM) medium did not affect nuclear maturation under our conditions (Table 2) with most oocytes in all three groups reaching metaphase II (MII) and extruding the first polar body.

No differences $(\mathrm{p}>0.05)$ in the relative amount of ZAR1, GDF9, BAX, MATER and HSP70 transcripts were observed between mBMP4 and mControl groups, indicating no differential degradation or de novo synthesis of these messengers in oocytes matured with BMP4. On

Table 2 Meiotic stages of oocytes

\begin{tabular}{lccccc}
\hline Treatment & Total & MII & MI & Other & Dead \\
\hline Control & 102 & $81(79.4)$ & $14(13.7)$ & $4(3.9)$ & $2(1.9)$ \\
BMP4 & 98 & $71(72.4)$ & $16(16.3)$ & 0 & $6(6.2)$ \\
Noggin & 89 & $72(80.8)$ & $10(11.2)$ & $2(2.2)$ & $5(5.6)$ \\
\hline
\end{tabular}

Meiotic stages, determined by nuclear staining of oocytes matured for $24 \mathrm{~h}$ in the presence of $100 \mathrm{ng} / \mathrm{ml}$ of BMP4 or Noggin. Control group was matured without any supplementation (Fisher test). MII: metaphase II; MI: metaphase I. Other: anaphase and telophase. the other hand, an up regulation of $M A T E R$ (mean factor: 2.484) and HSP7O (mean factor: 1.755) was observed in mNoggin oocytes (Figure 1).

\section{Parthenogenic activation}

After parthenogenic activation, mBMP4 and mNoggin embryos had higher $(p<0.05)$ cleavage rates than mControl but no effect on blastocyst production was found (Table 3).

\section{In vitro fertilization}

After in vitro fertilization, mNoggin cleavage rate was lower $(\mathrm{p}<0.05)$ than mBMP4 or mControl embryos. However, blastocyst rates were not affected ( $p>0.05$ ) indicating no effects of the treatments on advanced

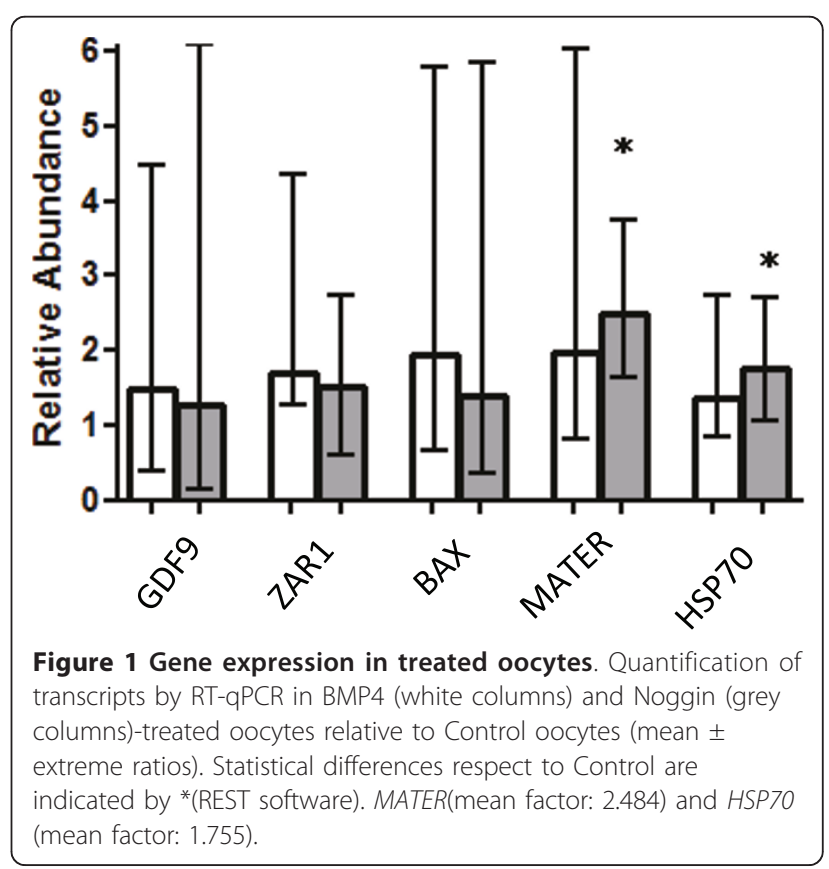


embryos. Similarly, the quantity of hatching embryos was not different $(\mathrm{p}>0.05)$ among groups (Table 3$)$.

No differences in embryonic cell numbers were found on day 2 (data not shown) in all groups and blastocysts from the three groups had similar total cell numbers for PA and IVF (Table 3). These data suggest that the early kinetics of development of these embryos were independent of BMP4 and Noggin during in vitro maturation.

\section{Oct-4 expression in PA and IVF embryos}

A higher proportion of Oct-4-expressing cells over total cells, was observed in mBMP4-PA blastocysts compared with mControl $(\mathrm{p}<0.01)$ and mNoggin $(\mathrm{p}<0.05)$ PA blastocysts. No differences among groups were found for IVF embryos (Table 4).

\section{BMP4 and Noggin during culture Parthenogenic activation}

In PA embryos, the cleavage rate and blastocyst formation were reduced $(\mathrm{p}<0.05)$ by Noggin when compared to $\mathrm{CBMP} 4$ and cControl embryos (Table 5), showing the importance of the BMP system for early stages of development.

On day two of culture there was a marked tendency ( $\mathrm{p}$ $=0.057$ ) for cNoggin to have a higher proportion of two-cell embryos (38\% vs. $29 \%$ ) and a lower proportion with five to eight cells (15.6\% vs. $17.7 \%)$ compared with Controls. This indicates some development retardation respect to Control. An opposite trend was observed in cBMP4, which had a higher $(\mathrm{p}=0.057)$ proportion of embryos with five to eight cells (25.4\% vs $17.7 \%$ ) compared to Controls. No difference in blastocyst total cell number was found between groups (Table 5).

\section{In vitro fertilization}

Noggin during culture negatively affected $(\mathrm{p}<0.05)$ cleavage, blastocyst and hatching rates while BMP4 addition reduced $(\mathrm{p}<0.05)$ blastocyst and hatching rates of IVF embryos (Table 5).

No differences in cell number of IVF embryos on day two of culture were seen so neither acceleration nor retardation in development was observed. Similarly to
PA embryos, no differences ( $p>0.05)$ in total cell number of IVF blastocysts were found among groups (Table $5)$.

\section{Oct-4 expression in PA and IVF embryos}

Proportions of Oct-4-expressing cells in IVF embryos were lower $(\mathrm{p}<0.01)$ in cBMP4 and cNoggin groups than in cControls (Table 6, Figure 2). No differences were found in this proportion between treatments in PA embryos (Table 6). The protein was localized in the ICM as well as in the trophoblast for all blastocysts.

\section{Discussion}

The effects of exogenous BMP4 or its inhibitor, Noggin, were studied during oocyte in vitro maturation or embryo culture. We found that whereas BMP4 and Noggin did not affect nuclear maturation, Noggin supplementation up-regulated the expression of HSP7O and MATER genes.

The HSP70 gene encodes a heat shock protein that binds several proteins and its over-expression is usually associated with stress [25]. In vascular tissues, Hsp70 protein can enhance BMP activity by binding BMP inhibitors and it can be a possible link between cellular stress and BMP signaling [26]. From our finding, we speculate that the increase of HSP7O transcripts could be an effort by the cell to keep BMPs at adequate levels or to minimize possible stresses induced by Noggin.

Mater is a maternal effect protein that plays an essential role on early embryo development in the mouse [27], but its role in other species is not well known. Mota et al [28] reported no variation in MATER gene expression between bovine oocytes with low and high competence. Whereas Pennetier et al [29] found that $M A T E R$ mRNA amount decreases strongly during maturation and Wood et al. [30] found over-expression in oocytes from women with polycystic ovarian syndrome. Our work found a higher relative abundance of MATER transcripts in oocytes matured with Noggin. This could be associated with a deficient cytoplasmic maturation nevertheless we did not find differences in blastocyst rates.

Table 3 Effect of BMP4 and Noggin added to in vitro maturation medium on development of parthenogenic and in vitro fertilized embryos

\begin{tabular}{|c|c|c|c|c|c|c|}
\hline & Treatment & Total & Cleaved (\%) & Blastocysts (\%) & Hatching blast. (\%) & Blastocyst cell number \pm sd \\
\hline \multirow{3}{*}{ PA } & Control & 344 & $190(55.2)^{\mathrm{b}}$ & $30(8.7)$ & & $100 \pm 33$ \\
\hline & BMP4 & 274 & $180(65.7)^{a}$ & $22(8.0)$ & $1(0.4)$ & $88 \pm 14$ \\
\hline & Noggin & 242 & $158(65.3)^{a}$ & $22(9.0)$ & & $68 \pm 8$ \\
\hline \multirow{3}{*}{ IVF } & Control & 249 & $176(70.7)^{\alpha}$ & $35(14.0)$ & $5(2.0)$ & $90 \pm 25$ \\
\hline & BMP4 & 221 & $160(72.4)^{\alpha}$ & $28(12.6)$ & $4(1.8)$ & $120 \pm 25$ \\
\hline & Noggin & 234 & $144(61.5)^{\beta}$ & $31(13.2)$ & $2(0.8)$ & $99 \pm 8$ \\
\hline
\end{tabular}

Development of parthenogenic (PA) and in vitro fertilized (IVF) embryos produced from oocytes that were matured in the presence of 100 ng/ml of BMP4 or Noggin. Controls were matured in standard medium without supplementation. Different superscripts in PA or IVF indicate statistical differences (Chi-square test, $\mathrm{p}<0.05)$. For blastocyst cell numbers, one-way ANOVA was applied. 
Table 4 Oct-4 expression in PA and IVF blastocysts from in vitro maturation experiments

\begin{tabular}{cccccc}
\hline & Treatment & $\mathbf{n}$ & $\begin{array}{c}\text { Total } \\
\text { cells }\end{array}$ & $\begin{array}{c}\text { Oct-4 positive } \\
\text { cells }\end{array}$ & $\begin{array}{c}\% \text { Oct-4/Total } \\
\text { cells }\end{array}$ \\
\hline PA & Control & 3 & 194 & 122 & $63^{\mathrm{b} * *}$ \\
& BMP4 & 2 & 100 & 79 & $79^{\mathrm{a}}$ \\
& Noggin & 3 & 240 & 157 & $65^{\mathrm{b} *}$ \\
IVF & Control & 2 & 136 & 103 & 76 \\
& BMP4 & 3 & 151 & 119 & 79 \\
& Noggin & 3 & 307 & 218 & 71 \\
\hline
\end{tabular}

Oct-4 expression in PA and IVF blastocysts produced from oocytes that were matured with $100 \mathrm{ng} / \mathrm{ml}$ of either BMP4 or Noggin, Controls were matured without supplementation. Different superscripts indicate statistical differences, 'Difference of proportions test' * $p<0.05 ;{ }^{* *} p<0.01$

We found that oocyte nuclear progression to the MII stage was not affected by the addition of BMP4 to the IVM medium which is consistent with Fatehi et al [4] results. In this work, we have also tested the effects of the inhibitor Noggin but no differences in nuclear maturation were observed.

Supplementation of media with BMP4 or its inhibitor during in vitro maturation had different effects on early embryonic development depending on whether the embryos were parthenogenic or in vitro fertilized with no effect on subsequent development. Similar results were published by Fatehi et al [4] only for maturation with BMP4 prior to IVF. However, despite blastocysts rates were similar, a higher proportion of Oct-4-expressing cells was observed in parthenogenic blastocysts obtained from oocytes matured with exogenous BMP4.

Although BMP4 has been well studied during organogenesis and extra-embryonic differentiation, BMP4 function during in vitro embryo development to the blastocyst stage has not been previously studied in the bovine. In a second set of experiments, we have addressed this study and BMP4 and Noggin were included in the embryo culture medium. We found that Noggin decreased cleavage, blastocyst and hatching rates of both PA and IVF embryos, showing the importance of BMP system for embryo development. This negative effect could be related to the lower proportion of Oct-4-
Table 6 Oct-4 expression in PA and IVF blastocysts from in vitro culture experiments

\begin{tabular}{cccccc}
\hline & Treatment & $\mathbf{N}$ & $\begin{array}{c}\text { Total } \\
\text { cells }\end{array}$ & $\begin{array}{c}\text { Oct-4 positive } \\
\text { cells }\end{array}$ & $\begin{array}{c}\text { \% Oct-4/Total } \\
\text { cells }\end{array}$ \\
\hline PA & Control & 3 & 163 & 129 & 79 \\
& BMP4 & 3 & 180 & 142 & 79 \\
& Noggin & 2 & 115 & 84 & 73 \\
IVF & Control & 3 & 275 & 229 & $83^{\mathrm{a}}$ \\
& BMP4 & 3 & 324 & 235 & $72^{\text {b** }}$ \\
& Noggin & 3 & 256 & 185 & $72^{\text {b** }}$ \\
\hline
\end{tabular}

Oct-4 expression in PA and IVF blastocysts. Embryos were cultured with $100 \mathrm{ng} / \mathrm{ml}$ of either BMP4 or Noggin, Controls were cultured without supplementation. Different superscripts indicate statistical differences, 'Difference of proportions test' ** $p<0.01$.

expressing cells observed in IVF embryos. Coincidently, the same effects on blastocyst formation and Oct-4 expression pattern were observed for BMP4 during the culture of IVF embryos. In mice, Murohashi et al [31] observed a lower ratio of ICM-derived cells over trophoectoderm-derived cells in blastocysts cultured and treated with Noggin, than Controls. It is possible that our results were related to similar effects on the pluripotency capacity of the embryos.

Although BMP4 addition to the culture medium did not affect cleavage rates for PA or IVF embryos, the rate of blastocyst production was reduced for IVF embryos, but not for PA embryos. These results suggest differences, in the BMP system, between PA and IVF embryos. This could be caused by the different imprinting pattern of both types of embryos [32]. PA embryos only contain maternal genome which could, in turn, cause differences at many levels e.g. expression of BMP ligands, receptors, intracellular mediators, etc.

In summary, we proof that Noggin, as BMP4, did not affect oocyte nuclear maturation. Noggin supplementation up-regulated the expression of HSP70 and MATER genes in matured oocytes. Moreover, BMP4 during maturation increased the proportion of Oct-4 positive cells in parthenogenic embryos. On the other hand, when Noggin was added to embryo culture medium, developmental rates of parthenogenic and in vitro

Table 5 Effect of BMP4 and Noggin added to culture medium on development of parthenogenic and in vitro fertilized embryos

\begin{tabular}{ccccccc}
\hline & Treatment & Total & Cleaved (\%) & Blastocysts (\%) & Hatching blast. (\%) & Blastocyst cell number \pm sd \\
\hline \multirow{2}{*}{ PA } & Control & 354 & $237(66.9)^{\alpha}$ & $48(13.5)^{a}$ & & $68 \pm 33$ \\
& BMP4 & 295 & $199(67.4)^{\alpha}$ & $44(14.9)^{a}$ & $1(0.3)$ & $91 \pm 43$ \\
& Noggin & 269 & $154(57.2)^{\mathrm{b}}$ & $19(7.0)^{\mathrm{b}}$ & & $71 \pm 16$ \\
IVF & Control & 218 & $138(63.3)^{\alpha}$ & $45(20.6)^{\alpha}$ & $10(4.6)^{\alpha}$ & $130 \pm 47$ \\
& BMP4 & 217 & $146(61.3)^{\alpha \beta}$ & $22(9.2)^{\beta}$ & $3(1.4)^{\beta}$ & $117 \pm 52$ \\
& Noggin & 205 & $105(51.2)^{\beta}$ & $24(11.7)^{\beta}$ & $1(0.5)^{\beta}$ & $128 \pm 21$ \\
\hline
\end{tabular}

Development of parthenogenic (PA) and in vitro fertilized (IVF) embryos cultured with $100 \mathrm{ng} / \mathrm{ml}$ of either BMP4 or Noggin, Controls were cultured without supplementation. Different superscripts in PA or IVF indicate statistical differences Chi-square test $(p<0.05)$. For blastocyst cell numbers, one-way ANOVA was applied. 


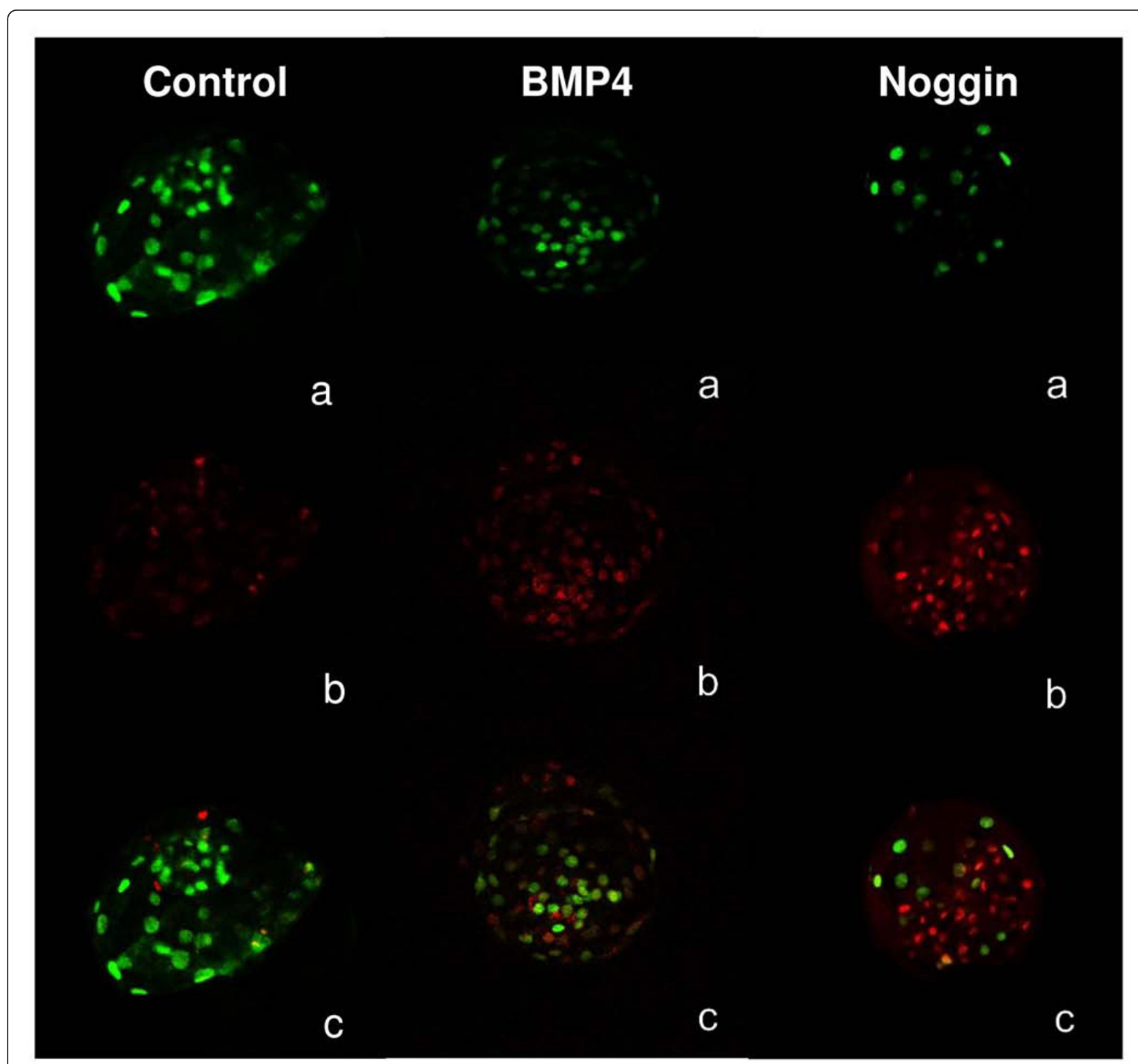

Figure 2 Oct- 4 expression in bovine blastocysts. Oct-4 immunostaining of blastocysts cultured with $100 \mathrm{ng} / \mathrm{ml}$ of either BMP4 or Noggin, Controls were cultured without supplementation. Confocal microscopy, augmentation: 20X and zoom: 2. a) Oct-4 positive cells (green); b) Total nuclei (red); c) Oct-4 positive cells and total nuclei (merged).

fertilized embryos were reduced. However, BMP4 addition decreases the development only for in vitro fertilized embryos. BMP4 and Noggin during culture reduced the proportion of Oct-4-expressing cells.

\section{Conclusions}

Our results show that BMP4 is implicated in bovine oocytes maturation with effects on cleavage rates and pluripotent state of blastocyst cells; and Noggin modifies the expression of some genes in oocytes. Moreover our findings demonstrate, for the first time, that a correct balance of BMP signaling is needed for proper preimplantation development of bovine embryos.

\section{Acknowledgements}

The authors want to thank Mr. Marcelo Danieli, Dr. Lucrecia Saez and Mr. Enrique Buix for kindly donations of ovaries from abattoirs. Also want to thank specially Dr. Karina Hodara for important help in statistical analysis.

\section{Author details}

'Laboratory of Animal Biotechnology, Agriculture Faculty, University of Buenos Aires (UBA), Argentina. ${ }^{2}$ Embrapa Dairy Cattle, Reproduction and Biotechnology, Dom Bosco, Juiz de Fora, M. G., Brazil. 'aboratory of Developmental Biology BBED, Exact and Natural Sciences Faculty, UBA, 
IFIBYNE-CONICET, Argentina. ${ }^{4}$ National Institute of Scientific and Technological Research (CONICET), Argentina.

\section{Authors' contributions}

ILR performed all the experiments but the RT-qPCR measurements and drafted the manuscript. LSAC contributed to the RT-qPCR analysis and gave critical discussion to the work. MMP performed the RT-qPCR experiments, RFM contributed in experiment design and draft of the manuscript. DAP contributed in experiment design and with immunocytochemistry experiments and DFS contributed in experiment design and draft of the manuscript. All authors read and approved the final manuscript.

\section{Competing interests}

The authors declare that they have no competing interests.

Received: 21 September 2010 Accepted: 1 February 2011 Published: 1 February 2011

\section{References}

1. Chen D, Zhao M, Mundy GR: Bone morphogentic proteins. Growth Factors 2004, 22(4):233-241.

2. Heldin $\mathrm{CH}$, Miyazono $\mathrm{K}$, ten Dijke P: TGF-beta signalling from cell membrane to nucleus through SMAD proteins. Nature 1997, 390(6659):465-471

3. Groppe J, Greenwald J, Wiater E, Rodriguez-Leon J, Economides AN, Kwiatkowski W, Affolter M, Vale WW, Belmonte JC, Choe S: Structural basis of BMP signalling inhibition by the cystine knot protein Noggin. Nature 2002, 420(6916):636-642.

4. Fatehi AN, van den Hurk R, Colenbrander B, Daemen AJ, van Tol HT, Monteiro RM, Roelen BA, Bevers MM: Expression of bone morphogenetic protein2 (BMP2), BMP4 and BMP receptors in the bovine ovary but absence of effects of BMP2 and BMP4 during IVM on bovine oocyte nuclear maturation and subsequent embryo development. Theriogenology 2005, 63(3):872-889.

5. Glister C, Kemp CF, Knight PG: Bone morphogenetic protein (BMP) ligands and receptors in bovine ovarian follicle cells: actions of BMP -4 , -6 and -7 on granulosa cells and differential modulation of Smad- 1 phosphorylation by follistatin. Reproduction 2004, 127(2):239-254

6. Knight PG, Glister C: TGF-beta superfamily members and ovarian follicle development. Reproduction 2006, 132(2):191-206.

7. Bristol SK, Woodruff TK: Follicle-restricted compartmentalization of transforming growth factor beta superfamily ligands in the feline ovary. Biol Reprod 2004, 70(3):846-859.

8. Elvin JA, C Yan, MM Matzuk: Growth differentiation factor-9 stimulates progesterone synthesis in granulosa cells via a prostaglandin E2/EP2 receptor pathway. Proc Natl Acad Sci USA 2000, 97(18):10288-10293.

9. Erickson GF, Shimasaki S: The spatiotemporal expression pattern of the bone morphogenetic protein family in rat ovary cell types during the estrous cycle. Reprod Biol Endocrinol 2003, 1:9.

10. Elis PS, Dupont J, Couty I, Persani L, Govoroun M, Blesbois E, Batellier F, Monget : Expression and biological effects of bone morphogenetic protein-15 in the hen ovary. J Endocrinol 2007, 194(3):485-497.

11. Silva JR, van den Hurk R, van Tol HT, Roelen BA, Figueiredo JR: Gene expression and protein localisation for activin-A, follistatin and activin receptors in goat ovaries. J Endocrinol 2004, 183(2):405-415.

12. Juengel JL, Hudson NL, Berg M, Hamel K, Smith P, Lawrence SB, Whiting L, McNatty KP: Effects of active immunization against growth differentiation factor 9 and/or bone morphogenetic protein 15 on ovarian function in cattle. Reproduction 2009, 138(1):107-114.

13. McNatty KP, Juengel JL, Wilson T, Galloway SM, Davis GH: Genetic mutations influencing ovulation rate in sheep. Reprod Fertil Dev 2001, 13(7-8):549-555

14. Fabre $S$, Pierre A, Mulsant $P$, Bodin $L$, Di Pasquale E, Persani $L$, Monget $P$, Monniaux D: Regulation of ovulation rate in mammals: contribution of sheep genetic models. Reprod Biol Endocrinol 2006, 4:20.

15. Fujiwara T, Dunn NR, Hogan BL: Bone morphogenetic protein 4 in the extraembryonic mesoderm is required for allantois development and the localization and survival of primordial germ cells in the mouse. Proc Natl Acad Sci USA 2001, 98(24):13739-13744.

16. Pan G, Thomson JA: Nanog and transcriptional networks in embryonic stem cell pluripotency. Cell Res 2007, 17(1):42-49.
17. Wang G, Zhang H, Zhao Y, Li J, Cai J, Wang P, Meng S, Feng J, Miao C, Ding M, Li D, Deng N: Noggin and bFGF cooperate to maintain the pluripotency of human embryonic stem cells in the absence of feeder layers. Biochem Biophys Res Commun 2005, 330(3):934-942.

18. Pant $\mathrm{D}$, Keefer $\mathrm{CL}$ : Expression of pluripotency-related genes during bovine inner cell mass explant culture. Cloning Stem Cells 2009, 11(3):355-365.

19. Kirchhof N, Carnwath JW, Lemme E, Anastassiadis K, Schöler H, Niemann H: Expression pattern of Oct-4 in preimplantation embryos of different species. Biol Reprod 2000, 63(6):1698-1705

20. Degrelle SA, Campion E, Cabau C, Piumi F, Reinaud P, Richard C, Renard JP, Hue I: Molecular evidence for a critical period in mural trophoblast development in bovine blastocysts. Dev Biol 2005, 288(2):448-460.

21. Soares M, Haraguchi S, Torres-Padilla ME, Kalmar T, Carpenter L, Bell G, Morrison A, Ring CJ, Clarke NJ, Glover DM, Zernicka-Goetz M: Functional studies of signaling pathways in peri-implantation development of the mouse embryo by RNAi. BMC Dev Biol 2005, 5:28.

22. Blomberg L, Hashizume K, Viebahn C: Blastocyst elongation, trophoblastic differentiation, and embryonic pattern formation. Reproduction 2008, 135(2):181-195.

23. Astorga J, Carlsson P: Hedgehog induction of murine vasculogenesis is mediated by Foxf1 and Bmp4. Development 2007, 134(20):3753-3761

24. Brackett BG, Oliphant $\mathrm{G}$ : Capacitation of rabbit spermatozoa in vitro. Biol Reprod 1975, 12(2):260-274.

25. Kregel KC: Heat shock proteins: modifying factors in physiological stress responses and acquired thermotolerance. J Appl Physiol 2002, 92(5):2177-2186

26. Yao $Y$, Watson $A D$, Ji S, Boström KI: Heat shock protein 70 enhances vascular bone morphogenetic protein-4 signaling by binding matrix Gla protein. Circ Res 2009, 105(6):575-584

27. Tong ZB, Gold L, Pfeifer KE, Dorward H, Lee E, Bondy CA, Dean J, Nelson LM: Mater, a maternal effect gene required for early embryonic development in mice. Nat Genet 2000, 26(3):267-268.

28. Mota GB, Batista Rl, Serapião RV, Boité MC, Viana JH, Torres $C A$, de Almeida Camargo LS: Developmental competence and expression of the MATER and ZAR1 genes in immature bovine oocytes selected by brilliant cresyl blue. Zygote 2010, 18(3):209-216

29. Pennetier S, Perreau C, Uzbekova S, Thélie A, Delaleu B, Mermillod P, Dalbiès-Tran R: MATER protein expression and intracellular localization throughout folliculogenesis and preimplantation embryo development in the bovine. BMCDev Biol 2006, 6:26.

30. Wood JR, Dumesic DA, Abbott DH, Strauss JF: Molecular abnormalities in oocytes from women with polycystic ovary syndrome revealed by microarray analysis. J Clin Endocrinol Metab 2007, 92(2):705-713.

31. Murohashi M, Nakamura T, Tanaka S, Ichise T, Yoshida N, Yamamoto T, Shibuya M, Schlessinger J, Gotoh N: An FGF4-FRS2alpha-Cdx2 axis in trophoblast stem cells induces Bmp4 to regulate proper growth of early mouse embryos. Stem Cells 2010, 28(1):113-121.

32. Ruddock NT, Wilson KJ, Cooney MA, Korfiatis NA, Tecirlioglu RT, French AJ: Analysis of imprinted messenger RNA expression during bovine preimplantation development. Biol Reprod 2004, 70(4):1131-1135.

33. Mourot M, Dufort I, Gravel C, Algriany O, Dieleman S, Sirard MA: The influence of follicle size, FSH-enriched maturation medium, and early cleavage on bovine oocyte maternal mRNA levels. Mol Reprod Dev 2006, 73(11):1367-1379.

doi:10.1186/1477-7827-9-18

Cite this article as: La Rosa et al.: Effects of bone morphogenic protein 4 (BMP4) and its inhibitor, Noggin, on in vitro maturation and culture of bovine preimplantation embryos. Reproductive Biology and Endocrinology 2011 9:18. 